\title{
Surveillance methods to determine tree health, distribution of kauri dieback disease and associated pathogens
}

\author{
N.W. Waipara ${ }^{1}$, S. Hill ${ }^{1}$, L.M.W. Hill ${ }^{1}$, E.G. Hough ${ }^{2}$ and I.J. Horner ${ }^{2}$ \\ ${ }^{1}$ Auckland Council, 8 Hereford St, Private Bag 92300, Auckland 1142, New Zealand \\ ${ }^{2}$ The New Zealand Institute for Plant \& Food Research Limited, Hawke's Bay, Private Bag \\ 1401, Havelock North, New Zealand. \\ Corresponding author: nick.waipara@aucklandcouncil.govt.nz
}

\begin{abstract}
Kauri dieback is a pest issue that is increasingly affecting kauri forests. A water and soilborne pathogen, Phytophthora taxon Agathis (PTA), has been identified as a causal agent of kauri dieback at multiple locations, particularly within Auckland and Northland. In 2008, a passive surveillance and adaptive management programme was initiated to manage the disease across the natural range of kauri. Surveys were initially undertaken to determine the distribution and rate of spread of kauri dieback on private land in the Auckland region. Methods to evaluate and monitor overall tree health, disease symptoms and other potential contributing factors were developed. Diagnostic sampling was undertaken to isolate and identify pathogens associated with kauri dieback. Along with PTA, other Phytophthora species and environmental stress were frequently associated with symptoms at over 400 properties inspected. Further management is now required to develop control tools and mitigate further spread.
\end{abstract}

Keywords kauri, Agathis australis, Phytophthora, biosecurity.

\section{INTRODUCTION}

Kauri (Agathis australis), a conifer in the Araucariaceae, is a dominant tree of lowland stands in northern New Zealand, frequently occurring in a mosaic of mixed forests of diverse composition (Ecroyd 1982). Following excessive exploitation for timber during the 19th and early 20th centuries, it is today virtually restricted to relatively small fragments (Steward \& Beveridge 2010). Kauri is an iconic species that is significant to all New Zealanders and a culturally significant toanga species to Maori. Ecologically, kauri is also a keystone species supporting a unique indigenous ecosystem and biodiversity (Ecroyd 1982).
During 2005-2006, observations of kauri 'illthrift' and tree mortality were reported from across the Waitakere Ranges Regional Park and Waipoua Forest, which led to surveys that identified the causal agent as Phytophthora taxon Agathis (PTA), commonly known as kauri dieback (Beever et al. 2009). Symptoms of PTA infection include: root rot, a collar rot causing large bleeding basal lesions, severe chlorosis, defoliation and tree mortality. It is a virulent primary pathogen that can rapidly kill seedlings and trees of all ages (Beever et al. 2010a) and therefore poses a threat to kauri and the kauri ecosystem generally. 
Kauri dieback was first reported from a natural stand of unhealthy kauri on Great Barrier Island (Gadgil 1974). There were no subsequent records until it was re-isolated from regenerating stands of kauri in the Waitakere Ranges. Between 2005-2010, kauri dieback was confirmed in other public forest reserves forests in Auckland and Northland, including Albany, Pakiri, Waipoua Forest, Trounson Kauri Park, Omahuta and Raetea Forest (Beever et al. 2009; Waipara et al. 2010). In October 2008 PTA was classified as an Unwanted Organism under the Biosecurity Act, and a national response and management programme was initiated by MAF Biosecurity New Zealand (now Ministry for Primary Industries), Tangata Whenua, Department of Conservation, and regional councils within the natural range of kauri (Waipara et al. 2010).

A passive surveillance programme was initiated by Auckland Regional Council to assist private land owners and the general public report suspected kauri dieback sites across the region. Publicity generated about public forest reserves being afflicted with kauri dieback led to numerous public complaints of possible symptoms of Phytophthora infection on individual ornamental trees through to large stands contained within privately owned land. This paper describes diagnostic field surveys on these properties undertaken in response to continued spread and new observations of symptoms.

\section{MATERIALS AND METHODS}

\section{Field assessment}

All public reports of possible kauri dieback were followed up with a site visit to assess likelihood of infection based on standardised visible symptoms compiled into a field symptom guide (Anonymous 2013). For each tree, location, size of trunk diameter at breast height $(\mathrm{dbh})$ and height were measured, photographed and health status assessed. Above ground symptoms were visually assessed including: presence, activity, type and size of bleeding lesions (gummosis). A canopy health rating was developed whereby each tree was scored (0-4), according to level of defoliation and branch death, with a score of '0-1' for an entirely healthy canopy and ' 4 ' for a dead tree. Other site and environmental variables contributing to poor tree health were described. These included: soil and root zone disturbance; proximity to tracks, roads and buildings; and agricultural and other human activities that had deleteriously damaged structural or fine feeder roots. These variables often confounded field-based diagnosis, so visual assessment of symptoms was complimented with soil and tissue sampling of symptomatic trees when required.

\section{Soil sampling}

A sterile trowel was used to collect $100 \mathrm{~g}$ of soil/ duff/roots from each of four cardinal points at the base of the trunk cone (larger mature trees), approximately $20 \mathrm{~cm}$ from the base of the stem cone (saplings) or $100 \mathrm{~cm}$ from the base of the trunk (juvenile and ricker trees), and from another four further points out towards the drip line of the canopy (Figure 1). Soil to a depth of $10 \mathrm{~cm}$ was collected, bulked into a single bag, and couriered to the Plant \& Food Research diagnostic laboratory at Havelock North for processing. Previously described baiting methods were used to detect Phytophthora in soil and included a modified method to specifically isolate PTA (Beever et al. 2010b).

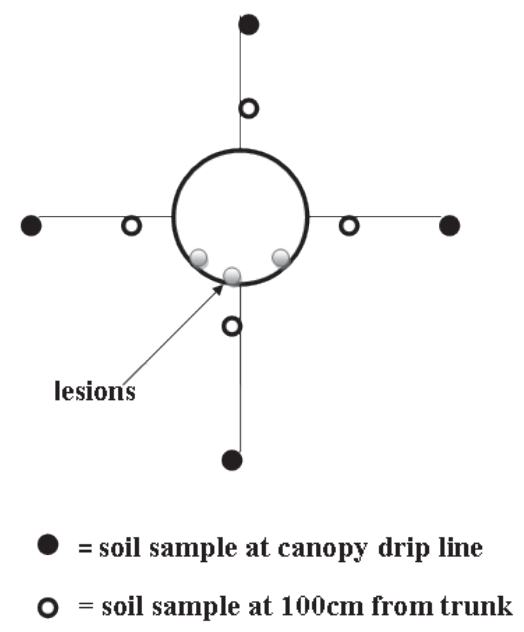

Figure 1 Sampling plan for soil collection in relation to lesion activity and canopy drip line of a symptomatic kauri (Agathis australis) tree (Source: Dr Tony Beauchamp, Department of Conservation, Whangarei, New Zealand). 


\section{Tissue sampling}

At a limited number of sites containing prioritised trees or stands, lesion tissue was excised from the cork cambium layer to detect Phytophthora and Armillaria presence. Using a surface-sterilised scalpel, sections $\left(5-10 \mathrm{~cm}^{2}\right)$ of necrotic tissue, within the outer cork cambium layer, were removed from behind the margin of freshly bleeding lesions and healthy bark.

Excised tissue was further dissected into smaller pieces $\left(5-15 \mathrm{~mm}^{2}\right)$ and plated onto $\mathrm{P}_{5} \mathrm{ARPH}-$ CMA, a Phytophthora selective agar (Beever et al. 2010b), within $72 \mathrm{~h}$ of sample collection. An elution process of placing excised tissues through continuous running tap water for a $12 \mathrm{~h}$ period to flush and reduce inhibitory resins and other phytocompounds, was undertaken to enhance detection rates, particularly when trees exhibited advanced lesion activity and wood decay.

Commercially available serological test-kits, or lateral flow devices (Pocket Diagnostic Test Kit ${ }^{\mathrm{TM}}$ http://www.pocketdiagnostic.com/products/31), were sporadically used during cambial sampling or plating to assess the generic presence/absence of Phytophthora in the tissue during the subsampling and dissection process.

\section{Isolation and identification of Phytophthora}

Baited isolates were sub-cultured from $\mathrm{P}_{5} \mathrm{ARPH}$ CMA agar onto V8 and potato dextrose agar for identification using cultural and oospore morphology. Representative isolates were also genetically sequenced using previously described molecular diagnostics for PTA and other Phytophthora species (Beever et al. 2009), and deposited into culture collections held at Plant \& Food Research or ICMP-Landcare Research.

\section{RESULTS}

From 2008 until March 2013, 436 properties were inspected across the Auckland region. Soil samples $(\mathrm{n}=164)$ and tissue samples $(\mathrm{n}=16)$ were processed during this period (Table 1). Tissue sampling emerged as being culturally unpopular with some landowners as they perceived the method to be invasive with added infection risks to their trees, and this led to a very low number of tissue samples being excised.

PTA was isolated from both soil and cambium samples taken from trees exhibiting either active or old lesions and/or some level of canopy thinning and foliar dieback (Table 2). Other Phytophthora species were also recovered from the soil associated with these symptoms, most frequently being $P$. multivora, which has not been formally reported from kauri in New Zealand in previous surveys (Table 1). Also isolated from soil were $P$. cinnamomi and P. cryptogea, both of which were historically identified from Auckland kauri as early as 1959 (Beever et al. 2009). Diagnostic taxonomic evaluation is underway to identify 38 Phytophthora isolates to species level where possible.

Lateral flow devices were successfully used at seven sites as a preliminary method to indicate

Table 1 Field and diagnostic results from a passive surveillance programme to isolate causal agents of kauri dieback disease on private land in the Auckland region.

\begin{tabular}{lrrr}
\hline Species & Number of sites & Field $^{1}$ & Sample \\
\hline Phytophthora taxon Agathis (PTA) & 107 & 65 & 42 \\
Phytophthora cinnamomi & 19 & 0 & 19 \\
Phytophthora cryptogea & 5 & 0 & 5 \\
Phytophthora multivora & 40 & 0 & 40 \\
Phytophthora spp. & 38 & 0 & 38 \\
Armillaria spp. & 5 & 0 & 5 \\
Nil recovery (no plant pathogens isolated) & 28 & 0 & 28 \\
Environmental ill thrift & 103 & 103 & 0 \\
Botanical misidentification - no kauri on site & 7 & 7 & 0 \\
No kauri dieback or ill thrift symptoms & 107 & 107 & 0 \\
\hline
\end{tabular}

${ }^{1}$ Diagnosis of kauri dieback disease determined using field symptoms. 
Table 2 Isolation of multiple pathogenic species from kauri trees displaying symptomatic kauri dieback during a passive surveillance programme on private land in the Auckland region. Two methods (soil and tissue) were used.

\begin{tabular}{lrrcc}
\hline Species isolated from soil and tissue samples & No. sites & Soil & Tissue & LFD $^{2}$ \\
\hline PTA alone & 22 & 16 & 8 & 6 \\
PTA + P. cinnamomi & 8 & 8 & 0 & 0 \\
PTA + P. multivora & 1 & 1 & 0 & 0 \\
PTA + Phytophthora spp. & 7 & 6 & 1 & 1 \\
PTA + Armillaria spp. & 1 & 1 & 1 & 0 \\
PTA + P. cinnamomi + Phytophthora sp. & 1 & 1 & 0 & 0 \\
PTA + P. cinnamomi + P. multivora + Phytophthora sp. & 1 & 1 & 0 & 0 \\
PTA + P. multivora + Phytophthora sp. & 1 & 1 & 0 & 0 \\
P. cinnamomi + P. multivora & 3 & 3 & 0 & 0 \\
P. multivora + Phytophthora spp. & 12 & 12 & 0 & 0 \\
P. multivora + P. cryptogea + Phytophthora sp. & 1 & 1 & 0 & 0 \\
P. cryptogea + Phytophthora sp. & 1 & 1 & 0 & 0 \\
Armillaria alone & 4 & 0 & 4 & 0 \\
\hline At some sil PTA was detect using both
\end{tabular}

${ }^{1}$ At some sites PTA was detected using both soil and tissue methods so there is an overlap in numbers. ${ }^{2} \mathrm{LFD}=$ lateral flow device.

presence of Phytophthora in excised tissues during sampling and plating (Table 2).

Hundreds of trees were observed exhibiting early and advanced symptoms of kauri dieback across the Auckland region (Table 3). Over 500 individual trees were either dead or in advanced stages of kauri dieback. Declining tree health due to Phytophthora infection disease or environmental stress was identified at many sites, with landowners expressing anecdotal concerns at the increasing number of trees exhibiting symptoms.

At 103 properties, symptoms were assessed as "ill thrift" due to environmental and site stressors, confirming previous Department of Conservation and Auckland Regional Parks unpublished observations, that kauri health is extremely vulnerable to soil disturbance
(Silvester 2006). Field observations determined that many amenity trees in ornamental situations were prone to multiple interacting stress factors that reduced soil, root and tree health. For example, unfenced kauri fragments on pastoral rural properties were often subject to soil compaction caused by livestock that may severely damage sensitive surface feeder kauri roots. Potential for soilborne vectoring of Phytophthora pathogens between unfenced rural kauri fragments was also observed. PTA has been frequently isolated from kauri rootzones exposed to significant soil disturbance by livestock (Beauchamp 2013). Movement of contaminated soil by livestock could potentially spread PTA to new infection sites particularly between stands of under-grazed forest.

Table 3 Field assessment of visible canopy and lesion symptoms.

\begin{tabular}{lcc}
\hline Canopy health rating: & Number of trees & Basal trunk lesions \\
\hline 0-1: no visible symptoms & 2165 & 329 \\
2: defoliation, sparse canopy & 644 & 321 \\
3: severe defoliation, branch death & 170 & 126 \\
4: dead canopy & 417 & $177^{1}$
\end{tabular}

${ }^{1}$ Presence of basal lesions could not be assessed on some dead trees that had advanced wood decay and had shedded dead bark. 
No kauri ill thrift or dieback was recorded at 107 properties (Table 1). These reports mostly arose due to landowners misdiagnosing natural physiological kauri resinosis and changes in foliage colour for symptoms of kauri dieback.

Tissue sampling resulted in direct cultural isolation of PTA at nine priority sites, as well as Armillaria infection being identified at five sites. Armillaria infection had resulted in copious basal gummosis that superficially resembled that induced by PTA lesion activity. A recent survey identified variability in the detection of PTA using soil baiting methods at some sites (Beauchamp 2013). Tissue sampling and lateral flow devices can be successfully used as complimentary diagnostic tools to assist in the detection of PTA (Table 2).

Multiple Phytophthora and Armillaria species were recovered from symptomatic trees at 38 sites (Table 2). This result may support the possibility of synergistic attack contributing to the overall decline or dieback. PTA was the most frequent Phytophthora species commonly isolated from symptomatic trees being identified in Auckland region.

A large number of trees also exhibited early stages of infection, with active basal trunk lesions and minor canopy defoliation (canopy ratings 1-2). Tree health monitoring has been implemented at many of these properties to assess rate of tree mortality in relation to age and size of infected trees, as well as inherent site variables, such as soil type, hydrology, topography, aspect and vegetation type.

Reports of a sudden collapse and rapid tree death were observed at 34 properties (Table 4). This symptom was commonly observed afflicting planted trees in amenity gardens and was associated with environmental stress and/or isolation of Phytophthora, particularly
P. multivora (Table 4). In contrast, PTA was only isolated once from a tree exhibiting sudden collapse, suggesting this is not a common symptom of PTA related kauri dieback.

\section{DISCUSSION}

Surveillance between 2008 and 2013 found that kauri dieback is widely distributed in the Auckland region. Distribution was predominantly in stands across the Waitakere Ranges, in rural fragments across the Rodney and Kaipara districts north of Auckland and the last remaining kauri remnants on the Awhitu Peninsula. Approximately 11,500 ha of private land containing kauri was estimated to be contaminated with PTA and was associated with severe symptoms and tree death. Landowner and public assistance was an important component of surveillance, and ongoing monitoring of kauri health has been implemented at many properties to assist with detection of new infection sites and estimate the rate of spread.

While PTA was the most frequently observed kauri pathogen, other pathogenic Phytophthora species and Armillaria were isolated from plants with dieback symptoms. Of note was the novel isolation of $P$. multivora from kauri and its potential association with sudden tree death at some sites. This organism was also identified in two recent disease surveys of Hebe stricta and kawakawa (Macropiper excelsum), where symptomatic plants were also afflicted with sudden collapse and rapid plant death (Ho et al. 2010). Koch's postulates and pathogenicity testing is required to assess relative risk and virulence of $P$. multivora on kauri, particularly in relation to kauri exhibiting sudden collapse.

Five species of Phytophthora were previously recorded from kauri or soil in kauri forests:

Table 4 Species isolated from kauri trees exhibiting sudden collapse and death during a passive surveillance programme on private land in the Auckland region.

\begin{tabular}{lc}
\hline Species isolated from soil samples & Number of sites \\
\hline PTA & 1 \\
P. cinnamomi & 2 \\
P. multivora & 11 \\
P. cryptogea + Phytophthora spp. & 1 \\
Phytophthora spp. & 6 \\
Environmental stress & 13 \\
\hline
\end{tabular}


P. cinnamomi, P. cryptogea, P. kernoviae, $P$. nicotianae and PTA, initially recorded as $P$. heveae (Beever et al. 2009). Phytophthora cinnamomi was linked with ill-thrift and tree death especially in naturally regenerating stands on poorly drained sites (Podger \& Newhook 1971) and can also cause seedling mortality (Horner 1984; Johnston et al. 2003). Pathogenicity of the remaining three species previously recorded from kauri is currently unknown (Beever et al. 2009).

Infection by Armillaria (A. novae-zelandiae and $A$. limonea) has been previously reported in both natural and planted kauri stands (Hood 1989; Dick 2009) and can reduce kauri health as a primary or secondary pathogen.

Isolation of multiple pathogenic agents from symptomatic trees may demonstrate synergistic attack or disease complexes that contribute to the overall poor health of kauri at these sites but further study is required to support this. In contrast, results indicated that sudden collapse and tree death may not be a common symptom of PTA-associated kauri dieback.

Results confirmed that kauri dieback is an important issue for private landowners with serious implications for future disease management. Anecdotal information provided by landowners suggests kauri dieback has been visibly emerging since the late 1990s on the Auckland mainland with continued spread resulting in new infection sites. Hundreds of trees have already succumbed to the disease at many sites, causing a health and safety issue for many landowners as standing dead trees were often in very close proximity to buildings, roads and human activity. Expensive tree removal and safe disposal is a direct economic impact to affected landowners.

Long term management is now required to contain the disease and protect healthy stands from infection. A public awareness campaign supported with phytosanitary and hygiene procedures has been implemented (Bellgard et al. 2009; Anonymous 2013). Control tools to mitigate the impact of kauri dieback are also urgently required by landowners and agencies. Phosphorous acid is a potential treatment being developed for controlling infected or threatened trees (Horner \& Hough 2013) and biological control options are also being trialled. However, containment and control of PTA will be difficult given the widespread and numerous disease foci identified to date.

\section{ACKNOWLEDGEMENTS}

Dr Ross Ewen Beever (1946-2010). Much of what we know of Phytophthora taxon Agathis is due to the pioneering investigation of the late Ross Beever. Ross recognised and confirmed the causal links between PTA, kauri dieback and its re-emergence 30 years after Peter Gadgil first described the phenomenon in 1974.

Tony Beauchamp, Stan Bellgard, Margaret Dick, Jacqui Brooks, Alastair Jamieson and Alison Davis provided pivotal observations, input and research that contributed to the development of surveillance and detection methods described in this paper. Jack Craw, Chris Green, Will Ngakuru, Fiona Bancroft, Jeanie McInnes, Ross Johnson and John Beachman are thanked for their contribution to the management, planning and implementation of the surveillance programme for kauri dieback.

\section{REFERENCES}

Anonymous 2013. Management and hygiene protocols to mitigate the soilborne spread of kauri dieback. www.kauridieback.co.nz (accessed 07 April 2013).

Beauchamp AJ 2013. The relationships between symptomology, detection probability and the detection of Phytophthora taxon agathis in the second round of surveillance sampling. Department of Conservation Report, DOCDM-1200160. Department of Conservation, Wellington, New Zealand. 35 p.

Beever RE, Waipara NW, Ramsfield TD, Dick MA, Horner IJ 2009. Kauri (Agathis australis) under threat from Phytophthora? Proceedings of the 4th International Union of Forest Research Organizations (IUFRO) Working Party 7.02.09. Phytophthoras in forests and natural ecosystems. Monterey, California, 26-31 August 2007. General Technical Report PSW-GTR-221. USDA, Forest Service, 
Albany, California, USA. Pp. 74-85.

Beever RE, Tsai S, Waipara NW, Dick MA, Ramsfield TD 2010a. Pathogenicity of Phytophthora taxon Agathis. Presentation at the 5th IUFRO Working Party S07.02.09, Phytophthora Diseases in Forests and Natural Ecosystems, Rotorua, New Zealand, 8-12 March 2010. p. 2.

Beever RE, Bellgard SE, Dick MA, Horner IJ, Ramsfield TD 2010b. Detection of Phytophthora taxon Agathis (PTA). Report for Ministry for Agriculture \& Forestry, Biosecurity New Zealand on behalf of Kauri Dieback Joint Agency. Landcare Research Contract Report LC0910/137, Landcare Research, Auckland, New Zealand. 78 p.

Bellgard SE, Paderes EP, Beever RE 2009. Kauri dieback: kauri hygiene - small project. Landcare Research Contract Report LC0910/017, Landcare Research, Auckland, New Zealand. 10 p.

Dick MA 2009. Resinosis on Agathis australis (Kauri). Forest Health News No. 201, December 2009. p. 1

Ecroyd CE 1982. Biological flora of New Zealand 8. Agathis australis. Kauri. New Zealand Journal of Botany 20: 17-36.

Gadgil PD 1974. Phytophthora heveae, a pathogen of kauri. New Zealand Journal of Forestry Science 4: 59-63.

Ho W, Thangavel R, Alexander B, Ashcroft T, Anderson P, Waipara N 2010. Phytophthora species associated with kawakawa tree decline in New Zealand. Presentation at the 5th IUFRO Working Party SO7.02.09 Phytophthora Diseases in Forests and Natural Ecosystems, Rotorua, New Zealand, 8-12 March 2010. p. 18.

Horner IJ, Hough EG 2013. Phosphorous acid for controlling Phytophthora taxon Agathis in kauri: glasshouse trials. New Zealand Plant Protection 66: 242-248.

Horner IJ 1984. The role of Phytophthora cinnamomi and other fungal pathogens in the establishment of kauri and kahikatea. MSc thesis, University of Auckland, Auckland, New Zealand.
Hood IA 1989. Armillaria root disease in New Zealand forests. New Zealand Journal of Forestry Science 19: 180-197.

Johnston PR, Horner IJ, Beever RE 2003. Phytophthora cinnamomi in New Zealand's indigenous forests. In: McComb J, Hardy G, Tommerup I ed. Phytophthora in forests and natural ecosystems. 2nd International IUFRO Working Party S07.02.09 Meeting, Albany, Western Australia. 30 September-5 October 2001. Murdoch University Print, Murdoch, Australia. Pp. 41-48.

Podger FD, Newhook FJ 1971. Phytophthora cinnamomi in indigenous plant communities in New Zealand. New Zealand Journal of Botany 9: 625-638.

Silvester W 2006. Managing access to heritage kauri trees - the siting of tracks and performance of track materials. Department of Conservation Report, DOCDM-45769. Department of Conservation, Wellington, New Zealand. 12 p.

Steward GA, Beveridge AE 2010. A review of New Zealand kauri (Agathis australis (D.Don) Lindl.): its ecology, history, growth and potential for management for timber. New Zealand Journal of Forestry Science 40: 33-59.

Waipara NW, Davis A, Hill SL, Brooks J, Pengelly M, Barr JA, Bellgard SE, Beever, RE 2010. Management of kauri dieback and Phytophthora taxon Agathis. Presentation at the 5th IUFRO Working Party S07.02.09, Phytophthora Diseases in Forests and Natural Ecosystems, Rotorua, New Zealand, 8-12 March 2010. p. 41. 